\title{
Facts about Calcium ${ }^{1}$
}

\author{
Linda B. Bobroff ${ }^{2}$
}

\section{Why do we need calcium?}

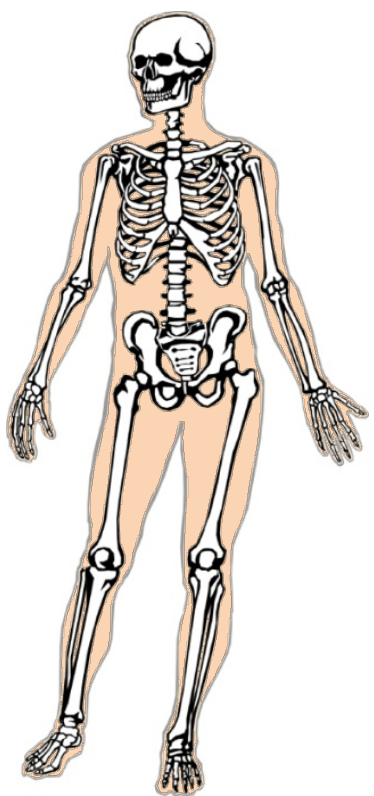

Calcium is the major mineral found in our bones and teeth. Along with phosphorus and other nutrients, calcium builds the hard structure that makes bones and teeth strong. We also need calcium for proper muscle and nerve function, blood clotting, and other body processes. These functions are so critical that calcium is taken from the bones to maintain blood calcium if dietary calcium is inadequate.

\section{What happens if we don't get enough calcium?}

We need calcium all through our lives to support our bones and teeth, and other body functions. We build most of the structure of

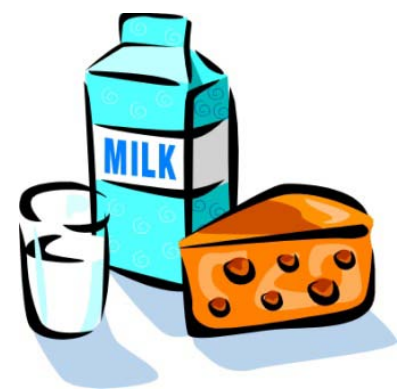

our bones before we reach 30 years of age. If we don't get enough calcium to make bones strong when we're young, we will be at risk for osteoporosis as we get older.

Osteoporosis is a condition in which bones are porous and weak. People with osteoporosis have a high risk of bone fractures. Hip fractures often result in loss of independence, so keeping bones strong is an important 赵 health goal.

\section{How do I know if I am at risk for osteoporosis?}

You may be at a higher risk for osteoporosis if you:

$>$ are White or Asian,

$>$ are small boned and thin,

$>$ have a family history of osteoporosis,

$>$ are a post-menopausal woman and don't take estrogen, take certain medications; ask a pharmacist for more information.

1. La versión en español de este documento es Datos Sobre el Calcio (FCS8703Span). This document is FCS8703, one of a series of the Department of Family, Youth and Community Sciences, Florida Cooperative Extension Service, Institute of Food and Agricultural Sciences, University of Florida. First published: June 2001. Revised: December 2008. Please visit the EDIS Web site at http://edis.ifas.ufl.edu

2. Linda B. Bobroff, Ph.D., RD, LD/N, professor, Department of Family, Youth and Community Sciences, Institute of Food and Agricultural Sciences, University of Florida, Gainesville FL 32611. 


\section{How much calcium do we need?}

The following table lists recommended daily intakes of calcium:

\begin{tabular}{|c|c|}
\hline Life Stage & $\begin{array}{c}\text { Calcium } \\
\text { (mg/day) }\end{array}$ \\
\hline Teens, ages 14-18 & 1300 \\
\hline Adults, ages 19-50 & 1000 \\
\hline Adults, ages 51+ & 1200 \\
\hline $\begin{array}{c}\text { Pregnancy } \\
\text { Ages 14-18 } \\
\text { Ages 19-50 }\end{array}$ & 1300 \\
\hline $\begin{array}{c}\text { Breastfeeding } \\
\text { Ages 14-18 } \\
\text { Ages 19-50 }\end{array}$ & 1000 \\
\hline mg = milligrams & 1000 \\
\hline
\end{tabular}

\section{How can we get enough calcium?}

For many Americans, dairy foods are the main sources of dietary calcium. People who are lactose intolerant have trouble digesting lactose - the sugar in milk.

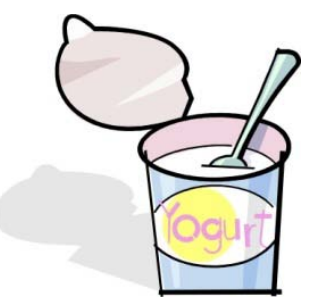
They can choose the many lactose-free milks and yogurts found in most grocery stores. Also, most people with lactose intolerance are able to drink small amounts of milk and eat cheese with no ill effects.

People who do not eat dairy foods have a hard time getting the calcium they need. Other food sources of calcium are calcium-fortified soy milk, orange juice and grains. Deep green leafy vegetables like kale, collards, and broccoli, and some types of tofu are also sources of calcium.
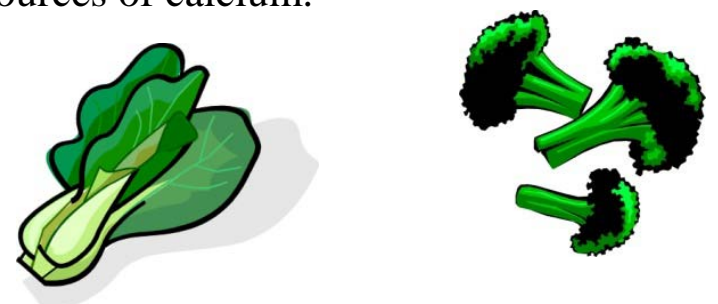

Here are some foods and the amount of calcium they contain:

\begin{tabular}{|c|c|}
\hline Food & $\begin{array}{c}\text { Calcium } \\
\text { (mg/serving) }\end{array}$ \\
\hline Tofu, raw, firm $1 / 2$ cup* & 860 \\
\hline Yogurt, low-fat, fruit, 1 cup & 370 \\
\hline Milk, low-fat (1\%), 1 cup & 300 \\
\hline Fortified soy milk, 1 cup & $200-300$ \\
\hline Fortified orange juice, $3 / 4$ cup & 200 \\
\hline Cheddar cheese, 1 ounce & 200 \\
\hline Cottage cheese, $1 \%, 1$ cup & 140 \\
\hline Collards, cooked, $1 / 2$ cup & 110 \\
\hline Kale, cooked, $1 / 2$ cup & 50 \\
\hline Broccoli, cooked, $1 / 2$ cup & 50 \\
\hline
\end{tabular}

\section{What about supplements?}

Women at risk for osteoporosis may need calcium supplements as part of their preventive care. If you are concerned about your bone health, speak to your doctor about your need for calcium. It is better to take calcium supplements throughout the day than all at once. If you use a supplement, do not get more than 2,500 $\mathrm{mg}$ of calcium per day from food and supplements together.

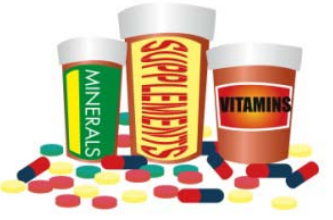

It is recommended that we take calcium supplements that contain vitamin $\mathrm{D}$, which is needed to absorb calcium. Do not take more than the recommended dosage unless your doctor tells you to do so. 


\section{Where can I get more information?}

The Family and Consumer Sciences (FCS) agent at your local Extension office may have written information and nutrition classes for you to attend. Also, your doctor or a registered dietitian (RD) can provide reliable information to you.

Reliable nutrition information may also be found on the Internet at the following sites: http://www.4woman.gov http://www.nutrition.gov http://www.nof.org

For more information about vitamin $\mathrm{D}$, see the UF IFAS Extension publication "Facts about Vitamin D” at http://edis.ifas.ufl.edu/FY207.

For more information about osteoporosis, see the UF IFAS Extension publication "Prevent Osteoporosis: Catch the Silent Thief" at http://edis.ifas.ufl.edu/FY469 (en español: http://edis.ifas.ufl.edu/FY997). 